Page 23I - 246

\title{
The Impact of Industrialization on The Regional Economic Development and Community Welfare
}

\author{
Sutikno', Muhammad Sri Wahyudi Suliswanto ${ }^{2}$ \\ 'University of Trunojoyo, ${ }^{2}$ Universitas Muhammadiyah Malang \\ 'tikno_fe_utm@yahoo.com, ªl.ayudie@gmail.com
}

\begin{abstract}
This study was aimed to determine the impact of industrialization on the regional economic development. Gresik regency was chosen as the research setting for it is one of largest industrial areas in East Java. The analysis instruments used were: First, the regression analysis, to determine the impact of industrialization on economic growth, unemployment, and poverty. Second, Confirmatory Factor Analysis (CFA), it was used to investigate the impact of industrialization on the community welfare. Third, Monte Carlo simulation that used to formulate a recommendation. The result showed that the industrialization in Gresik still has not been able to give extensive significant impact for the community in Gresik regency and its existence can only be enjoyed by nearby residents. Based on the simulation results, showed that the strong commitment between Gresik local government and the industry in order to address the problem of unemployment is very necessary due to its' greatest impact.
\end{abstract}

Keywords: industrialization, economic development, community welfare

\begin{abstract}
Abstrak
Penelitian ini bertujuan untuk melakukan pengujian dampak industrialisasi terhadap pembangunan ekonomi daerah. Kabupaten Gresik dipilih menjadi objek penelitan karena merupakan area industrialisasi terbesar di jawa Timur. Teknik analisis yang dipergunakan ialah: Pertama, analisis regresi yang digunakan untuk menentukan dampak industrialisasi terhadap pertumbuhan ekonomi, pengangguran, dan kemiskinan. Kedua, analisis faktor untuk melakukan investigasi dampak industrialisasi terhadap kesejahteraan masyarakat. Ketiga, simulasi Monte Carlo untuk merumuskan rekomendasi. Hgasil menunjukkan bahwa industrialisasi yang terjadi di Gresik masih belum mampu memberikan dampak terhadap masyarakat di Kabupaten Gresik, eksistensi industrialisasi hanya dirasakan oleh daerah sekeliling saja. Berdasarkan simulasi, menunjukkan komitmen kuta pemerintah Kabupaten Gresik dan industry untuk mengentaskan masalah pengangguran.
\end{abstract}

Kata Kunci: industrialisasi, pembangunan ekonomi, kesejahteraan masyarakat

Received: April 29, 2017; Revised: May 30, 2017; Approved: June 18, 2017 
The Impact of Industrialization on The Regional...

Sutikno, Muhammad Sri Wahyudi Suliswanto

\section{INTRODUCTION}

Industrial sector has an important role and position for long-term economic development in many countries. Industrialization expected to be the primary solutions to accommodate the increasing population in the agricultural sector and the beneficial stimulant to increase activities in other areas of community life which is expected to increase production and national income in general, either directly or indirectly. Higher national income can increase the propensity to support and provide the availability of funds that necessary for further investment.

The degree of industrialization in a country / region is reflected by the level of development, not only from the primary industry, but also in other secondary industry of the countries / areas. The level of industrial development is not only measured by the percentage of growth in output or a share of its output to GDP / GRDP and its contribution to total export value, but also by the level of diversification of products or variations of goods made, according to the type of user (consumer goods, capital, semi finished materials, the means of production or raw materials are processed), or by technological content (low, medium or high). However, even if a country / area has a large primary industries (many product variations), but weak in the secondary industry, it cannot be said that the level of industrialization in the country / region is high. In fact, in a lot of literature on industrialization, more attention is given to the manufacturing industry (Tambunan, 1999). It means that many people interpret industrialization in sectoral, which is a change from a certain sector, especially the agricultural sector, to the manufacturing sector. Although industrialization should not be grouped by sector for industrialization can occur in all sectors, it should be interpreted as an innovation in the production system, which is sourced from the results of a research development and application of science. In a narrower sense, industrialization is a process of production of goods and services with a comprehensive use of resources.

In Gresik, industrialization (which is presented by the growth of manufacturing industry and measured from the output growth percentage) has not shown its real function in local economic development yet. The indication can be seen from the contribution of manufacturing sector on Gross Regional Domestic Product (GRDP) of Gresik which were always dominant each year, which is able to support the high 
growth of the local economy and achieving the number above the national economic growth in the year 2013 but was not able to be a stimulant to increase activity in other fields in community life. The unemployment rate is still high and the levels of poverty as well. The high economic growth in Gresik, which is a product of industrialization is still artificial, has not good quality, and has not been able to give a positive impact on the fundamental issues faced by Gresik. Based on the description above, the study aims to identify the impact of industrialization on economic growth, employment (unemployment), poverty, and social welfare.

\section{METHOD}

This study chose Gresik as the research setting since it is one of potential industrial area in East Java. The data used in this research are secondary and primary data. Secondary data were obtained from the regional offices of industry, labor offices, as well as district offices, or other institutions related to these activities. While primary data obtained through interviews and questionnaires.

The sample of the study is eligible to be called an internal sampling. In internal sampling, samples are not used in an attempt to make statistical generalizations or merely represent the population (as in external sampling), but rather leads to theoretical generalization. Sources of data used are not to represent the population, but tend to represent the information; the completeness and depth are not particularly need to be determined by the number of data sources. Consequently, the number of sample did not specify the accuracy of the activity / research. In fact, one sample is sufficient.

The selection of location in this activity using criterion-based selection, the choice of which is based on certain criteria in order to obtain comprehensive data of the background and specific events to achieve the completeness of the information (Alwasilah, 2003; Kanto, 2003). This research was conducted in selected districts throughout Gresik, except in Bawean Island. There are several things to be considered as the criterion in determining the location of the study, namely: the suitability of the location with the theoretical framework, the operational technical as whether the location can be entered and studied more deeply, as well as the possibility to approach the social structure. Moreover, geographical and practical limitations should also be considered such as time, cost, and effort (Moleong, 2000; Yuswadi, 2003). 
The Impact of Industrialization on The Regional...

Sutikno, Muhammad Sri Wahyudi Suliswanto

The criteria in determining the location of industrial districts selected are: (I) The districts represent areas with high intensity of industrial investment; (2) The districts represent areas with low industrial investment intensity; (3) The districts represent areas with high levels of poverty; (4) The districts represent areas lower poverty levels; (5) The districts represent the geographical aspects of the surrounding area.

The analytical instruments used in this research are: First, the regression analysis, which is used to determine the impact of industrialization on economic growth, unemployment, and poverty. Independent Variable (X), that is the investment as a representation of industrialization and the Dependent variable $(Y)$ that includes economic growth (YI), unemployment (Y2), and poverty (Y3). Second, Confirmatory Factor Analysis (CFA), which was used to determine the impact of industrialization on the welfare of the community. This analysis is used to examine how the variables measured (indicators) depict or represent a number of constructs.

Third, in order to determine its implications, this study should perform simulations on the recommendations drawn up to address the impacts that are not expected from industrialization by applying the relevant simulation models, such as Monte Carlo. Monte Carlo simulation is a sampling using random numbers (random numbers) done by the computers. The working principle of the Monte Carlo simulation is to generate random numbers or a sample of a random variable where the distribution has been identified. Monte Carlo simulation is a powerful modification tool to solve complex problems in the field of probability and statistics.

\section{Result and Discussion}

The economic growth in Gresik progressing rapidly, compared with other areas in East Java. One of the boosters of the economics growth in Gresik is the industrial sector. There are many large and small industries in Gresik, including the two major state-owned companies such as PT. Petrokimia Gresik and PT. Semen Gresik.

Gresik also has several industrial zones including the Gresik Industrial Zone (KIG) and the Maspion Industrial Zone. Within the region, there are foreign and domestic industries that expand their business in the region, and there are also a lot of companies that are located outside the industrial zones in Gresik. Additionally, there are also some small businesses that develop rapidly in Gresik, such as the 
manufacturing industry of kopyah or Peci (cap widely worn in Indonesia, Brunei, Malaysia, Singapore, the southern Philippines and southern Thailand, mostly among Muslim males). This industry has expanded the national and international markets.

Industrialization impact on local economic development will be measured using investment as a representation of industrialization and the use of economic growth, unemployment, and poverty variables as a representation of regional economic development. First, to measure the impact of industrialization, represented by the variable of Investment (I), on the Economic Growth (Y), this study carried out a test using a simple linear regression, while the model of analysis results can be interpreted as follows:

$$
\begin{aligned}
& Y=\beta_{0}+\beta_{1} X_{1}+\varepsilon_{t} \\
& Y=8.05 \text { to } 0.14 I
\end{aligned}
$$

The value of $\beta_{0}=8.05$, means that the economic growth $(Y)$ of 8.05 at the time of investment equal to or considered zero (constant). While the value of $\beta_{1}=$ regression coefficient of Investment variable (I) of -0.14 means that there are negative effects of investment on economic growth by 0.14 . Based on tests of significance, the investment variable has no significant effect on the economic growth; this means Industrialization in Gresik did not have an impact on economic growth. These results support research from Sulistiawati (2012) which states that investment is not significant effect on economic growth with data of 33 provinces in Indonesia in 2006 to 2010.

Industrialization process in Gresik has not been able to encourage the economic growth in this region. In fact, other variables that are apart from industrialization were the ones that contributed greatly to the high economic growth in this regency. Theoretically, high level of investment should have been able to push the high economic growth rate, yet this does not happen in Gresik. This means that there is a lost connection between the process of industrialization and economic growth.

Second, the results of measuring the impact of industrialization, represented by the variable of Investment $(I)$, on the unemployed $(U)$ are as follows: 
The Impact of Industrialization on The Regional...

Sutikno, Muhammad Sri Wahyudi Suliswanto

$$
\begin{aligned}
& U=\beta_{0}+\beta_{1} X_{1}+\varepsilon_{t} \\
& U=0.64+0.30 I
\end{aligned}
$$

The values of $\beta_{0}=0.64$, which indicates that the Unemployment $(U)$ of 0.64 at the time of investment equal to or considered zero (constant). While the value of $\beta_{1}=$ regression coefficient of Investment variable (I) of 0.30 means that there is a positive influence between investments on unemployment of 0.30 . Based on tests of significance, the variable investment not significantly affect the unemployment level, industrialization in Gresik did not have an impact on unemployment at all.

The process of industrialization in Gresik has not been able to create fields of work that are balanced with the growth rate of the working boost to overcome unemployment in Gresik, the problem of unemployment more assisted by other variables than the process of industrialization. Theoretically, high level of investment should be able to open more job opportunities, but this did not happen in Gresik. This indicates that investment fields are shifting from labor-intensive to capital-intensive areas. As it shifts into the capital-intensive field, the effect of labor absorption becomes little per capital expended. Minimally absorption of labor causes fewer prosperity effects (Sumanto, 2016)

Third, the results of measuring the impact of industrialization represented by variables of Investment (I), on Poverty $(\mathrm{P})$ are as follows:

$$
\begin{aligned}
& P=\beta_{0}+\beta_{1} X_{1}+\varepsilon_{t} \\
& P=-35.8 I+4.54 I
\end{aligned}
$$

The value of $\beta_{0}=-35.8 \mathrm{I}$, which means that Poverty $(\mathrm{P})$ of $-35.8 \mathrm{I}$ at the time of investment equal to or considered zero (constant). While the value of $\beta_{1}=$ regression coefficient of Investment variable (I) of 4.54 means that there is a positive influence between investments on poverty of 4.54 . Based on significance test at $\alpha=5 \%$, the variable of investment does not affect significantly the level of poverty. Even At $\alpha=$ $10 \%$, industrialization in Gresik, was actually creating new spaces for the poverty problem in Gresik. As is the case in Bali Province, based on Awandari and Indrajaya research (2016) which states that investment has no significant effect on welfare in Bali Province. 
The process of industrialization in Gresik cannot be the main policy options for overcoming poverty in Gresik, the poverty rate more assisted by other variables than the process of industrialization. In theory, high level of investment should be able to push employment opportunities thus the poverty rate will decrease, but this did not happen in Gresik. This means that there is a missing connection between the industrialization process and the chance to get a job in Gresik.

In addition to analyzing the impact of industry on the region's economic development, this study also investigate the industry's role on the welfare of the surrounding community by using Confirmatory Factor Analysis (CFA), this analysis is used to examine how the variables measured (indicators) either depict or represent a number of construct. CFA is used to test the assertion of the theory of measurement that determines how the variables measured logically and systematically describe the role of increased revenue due to the existence of the industry, the industry attention to the surrounding community, and job opportunities on the community welfare. Based on the analysis Confirmatory Factor Analysis (CFA), the loading factor values can be seen as follows:

Figure I. Relationship of Each Variable

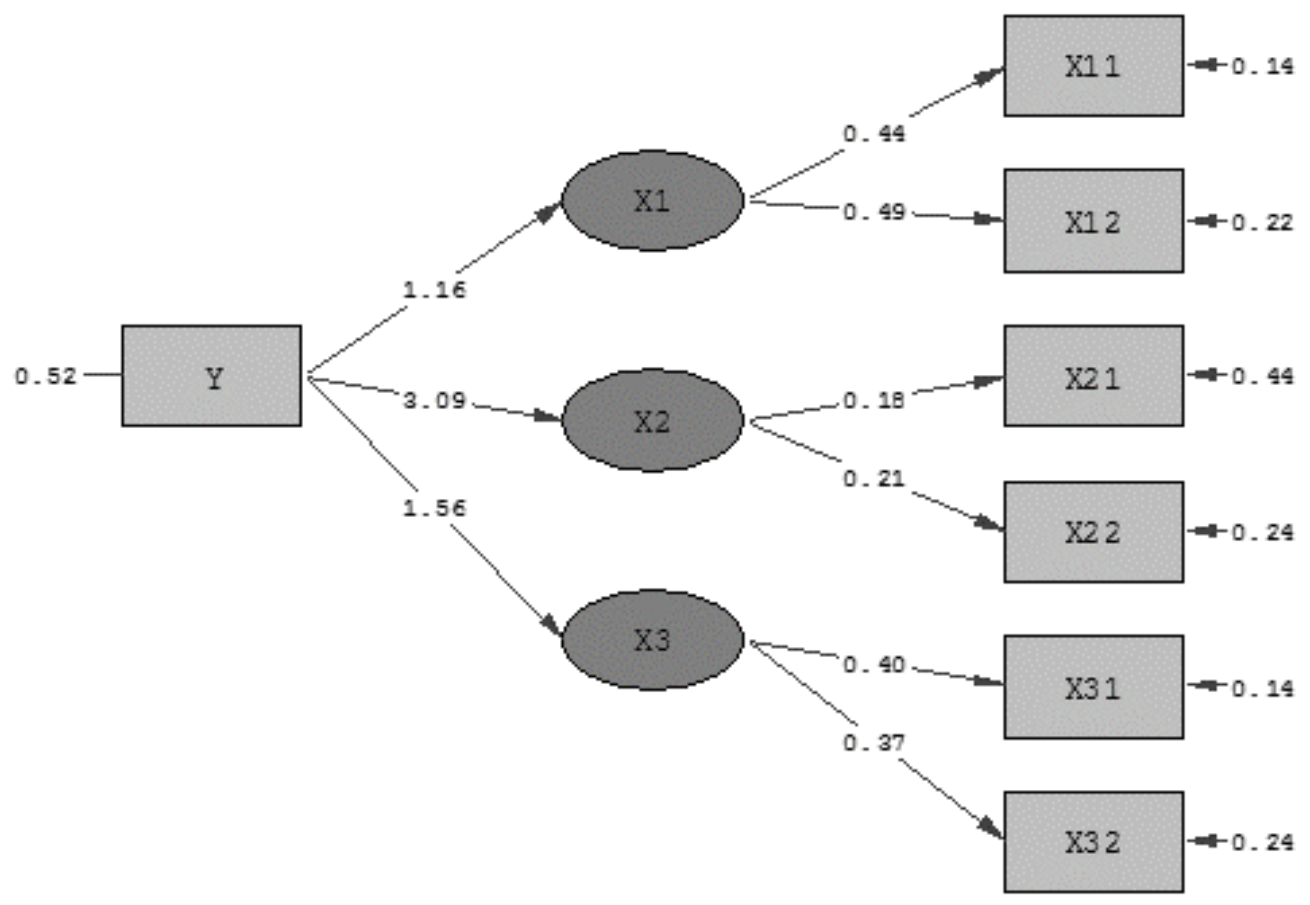

Chi-9quare $=107.64, d f=12, P-v a l u e=0.00000$, RMSEA $=0.270$ 
The Impact of Industrialization on The Regional...

Sutikno, Muhammad Sri Wahyudi Suliswanto

Based on Figure I, it can be seen that the most important indicators that contribute to the formation of Increased Revenue variable due to the presence of industry $\left(X_{1}\right)$ is improving business $\left(X_{12}\right)$ with a correlation value of 0.49 . Another indicator is Opening a new business $\left(X_{11}\right)$, which has a correlation value of 0.44 . Indicators, which are crucial to the formation of Industrial Attention on Neighborhood Community variables $\left(X_{2}\right)$ is Helping people around $\left(X_{22}\right)$ with a correlation value of 0.21 . Another indicator is Granting $\operatorname{CSR}\left(\mathrm{X}_{21}\right)$, which has a correlation value of 0.18. Indicators, which are crucial to the formation of Opening Employment variable $\left(X_{3}\right)$ is Giving a permanent job $\left(X_{31}\right)$ with a correlation value of 0.40 . Another indicator is giving a part time job (wholesale) $\left(X_{32}\right)$, which has a correlation value of 0.40 .

While the most important variables that hold significant role towards the establishment of community welfare variable ( $Y$ ) is Industrial Caring on Community Neighborhood $\left(X_{2}\right)$ with a correlation value of 3.09. The next variables, namely Job opportunities $\left(X_{3}\right)$, and increased income due to the existence of the industry $\left(X_{1}\right)$ with the respective correlation values of $\mathrm{I} .56$ and I.I6.

The results of data processing analysis show that the constructs that were used to form a research model, during the process of confirmatory factor analysis has met the goodness criteria of fit that have been set. Probability value of goodness of fit testing shows the value of 0.000 which indicates the model is good, and the results of model fit as predicted with the values of other observations already qualifies as well as the value of Normed Fit Index $(\mathrm{NFI})=0.83$; Non-normed Fit Index $(\mathrm{NNFI})=0.73$; Comparative Fit Index $(\mathrm{CFI})=0.85$; Incremental Fit Index $(\mathrm{IFI})=0.85$; and Relative Fit Index $(\mathrm{RFI})=0.7 \mathrm{I}$.

Tests of significance in this model can be used by t-test. The t-test was used to determine whether each independent variable partially have a significant influence on the dependent variable. Based on Figure 2, it can be seen that all variables showed significant numbers, $\mathrm{t}$ table $(\alpha=0.05$; $\mathrm{db}$ residual $=\mathrm{I0I})$ is $\mathrm{I}, 980$. Since all variables showed $t$ count $>t$ table, it can be concluded that the Establishment of community welfare around the industry Variable can be affected by the role of increasing of income due to the existence of the industry, the industry attention to the surrounding community, and employment opportunities. 
Figure 2. The significance test (t test)

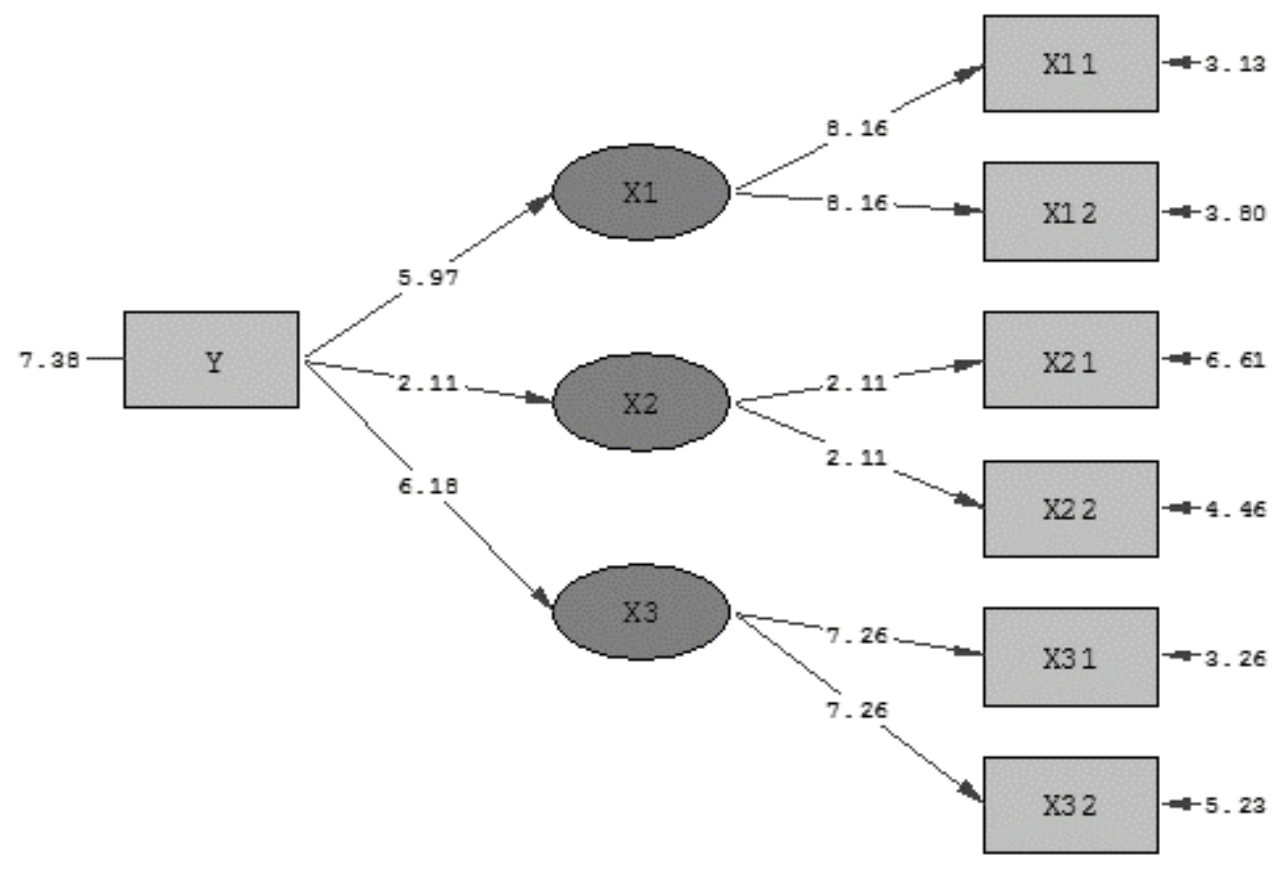

Chi-Square=107.64, df=12, P-value $=0.00000$, RMSEA $=0.270$

In order to obtain more detailed information related to variables that will be put as the priority, this study formulate the average value quadrant and loading factor as seen in Figure 3.

Quadrant I: In this position, the indicator has a higher loading factor and high average value. Indicators, which exist in this position ought to be maintained. On this indicator, it is more appropriate to explain about what things have been made, so that the indicators in this position can serve as an example for other variables. Indicator that presents in this position is $\mathrm{XII}$ (Opening a new business).

Quadrant II: In this position, the indicator has a low loading factor and high average value. Indicators in this position have "weaker" (not the main indicator) contribution. Indicators that are in this position are X2I (Granting CSR) and X22 (Helping people around).

Quadrant III: In this position, the indicator has a higher loading factor and the low average value. Indicators in this quadrant ought to be a "major priority" due to have a higher loading factor but the average value is still low. On this indicator, it is more appropriate to explain about what things that will be done, so that these indicators can be applied well or in other words, "new attempt" what should be 
The Impact of Industrialization on The Regional...

\section{Sutikno, Muhammad Sri Wahyudi Suliswanto}

implemented so that the average indicator could be better. Indicators that are located in this quadrant are XI2 (Increase business), X3I (Giving a permanent job), X32 (Giving a part time job (wholesale)).

Quadrant IV: In this position, the indicator has a low loading factor and the low average value. Indicators that stand in this quadrant are the weakest, so it is important to know why this happened. There are no indicators in this position.

Figure 3. Average Value Quadrant and Loading Factor

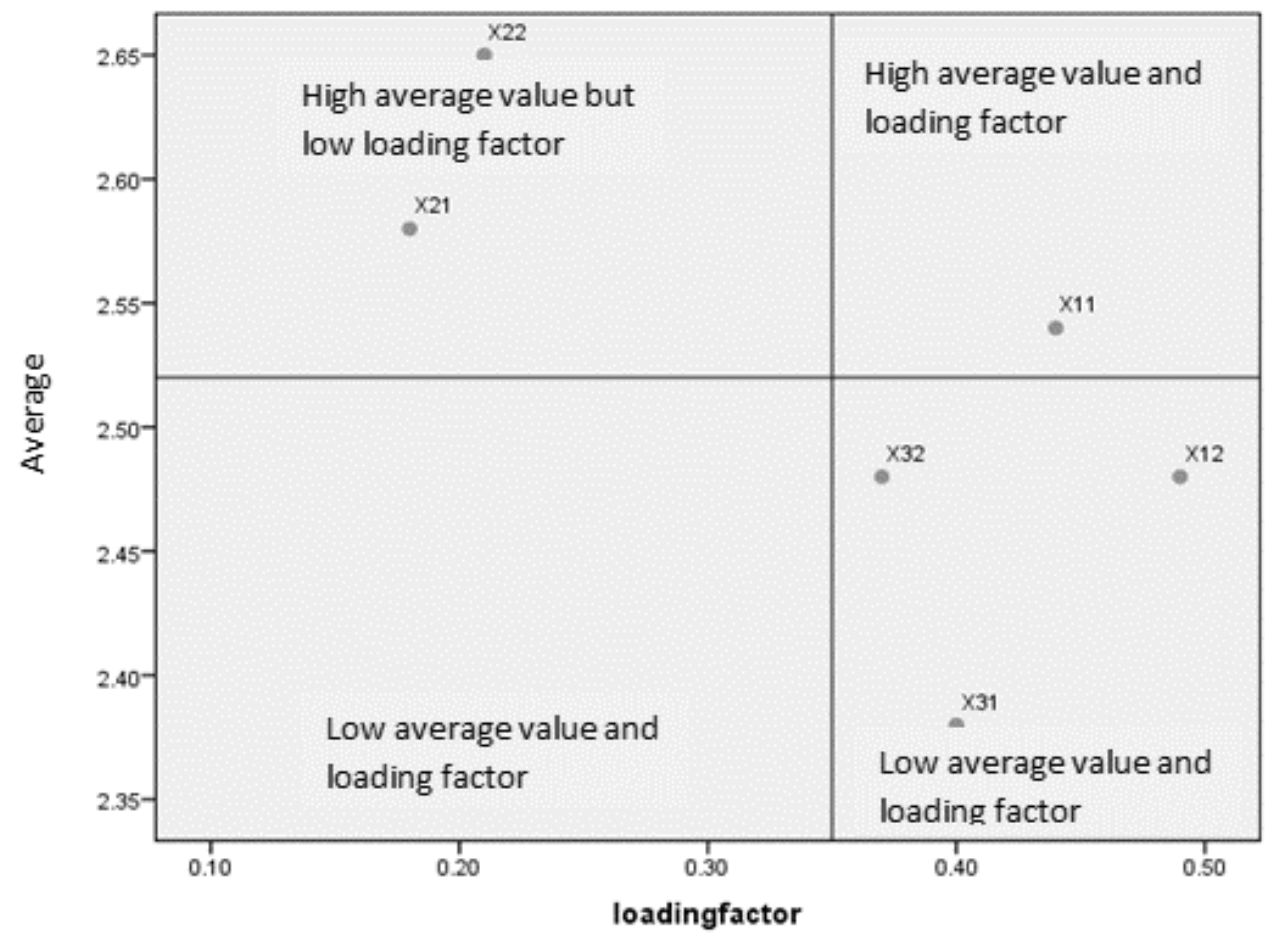

Based on the results of previous analysis, the study found that industrialization in Gresik not had a significantly impact to the macro conditions such as economic growth, unemployment, and poverty. These results support the results of research from Sulistiawati (2012); Sumanto (2016); Awandari and Indrajaya (2016). But for the people around the industry, it could have a significant impact as a result of research from Erista (20I4); Istiqomah \& Prasetyani (20I3); and Rahmadhani \& Herianingrum (2017). Before outlining the results of the analysis as to why that happens, researchers will explain the meaning of the impact itself. The impact is a change caused by an activity, a business investment in development activities, which have potential to create an impact. 
Thus, Soemartono in Syahputra (2016) explains that, basically, the target of development is to raise the level of prosperity, but the development activities, which have side effects that are not planned beyond the target so-called impact. The impact can be biophysical, social, economic and cultural that influential on the targets to be achieved. Meanwhile, Soedharto in Armi, et.al (2016) stated that social impact is social consequences or changes that occur in human beings and society as a result of a development activity or the implementation of a policy and program.

This condition is reinforced by two facts that can be used as an assertion or strengthening of the condition. First, the facts regarding industrial location, in Gresik there are approximately 512 large and medium industries. But the existence of these industries are not scattered throughout the region of Gresik, most of these industries are located in Districts of Wringinanom, Driyorejo, Manyar and Kebomas. This is the reason why industrialization in Gresik has less significant influence macroeconomic conditions. The second fact is about poverty enclaves in Gresik. Based on the data revealed by the Central Bureau of Statistics in Gresik, the highest numbers of disadvantaged families are presented in the Districts of Balongpanggang, Menganti, and Kedamean. Those districts are not the centers of industry in Gresik. While other areas that become the centers of industry in Gresik have relatively low rate of poor citizens. Here is an overview of industry center locations and poverty enclaves in Gresik.

The centers of industrial location in Gresik are located in the border region of Sidoarjo and Surabaya, as well as in the central city of Gresik; while the poverty enclaves are mostly situated in Districts of Balongpanggang, Menganti, and Kedamean, which is far enough from the industrial site. This indicates that Gresik experiences regional gap phenomenon. The industrial area is highly developed; while other areas that are not become the central industrial location is relatively undeveloped. This is also strengthened by the fact that the Gini index value of Gresik in 2013 was 0.57 . This value is classified into Gini Ratio> 0.5 which shows high inequality. Additionally, the high inequality in Gresik can also be seen from the inequality index of Williamson (Regional Inequality Index). Based on these indicators, the index of inequality Williamson (Regional Inequality Index) of Gresik in 2013 was 0.74.

Thus, we can conclude that the presence of industrial areas in Gresik has not been able to create significant impact on the macro economy Gresik, yet it greatly 
The Impact of Industrialization on The Regional...

Sutikno, Muhammad Sri Wahyudi Suliswanto

impacts the surrounding community. This is answer to the question why the industrialization in Gresik not significantly affects the macro-economic conditions there. Therefore, the government must carry out concrete efforts to provide policy in order to enlarge the impact of industrialization in Gresik to communities that live farther from industrial areas through socialization of industrial workers opportunities to the community and providing employment in accordance with the needs of industries in Gresik. Besides, the government should also make a policy to regulate the location of industrial centers; especially for underdeveloped areas in Gresik so the broader impact can be felt by the people in those disadvantaged regions.

As recommendations to overcome this problem, researchers used Monte Carlo analysis. Monte Carlo is a computational algorithm to simulate the behavior of various systems of physics and mathematical. The use of classic method is to evaluate definite integrals, particularly multidimensional integrals with complicated conditions and restrictions. Monte Carlo simulation is very important in computational physics and other applied fields, and has diverse applications from esoteric quantum thermodynamics up to the aerodynamic design.

Monte Carlo is a numerical approximation method. As other numerical methods, Monte Carlo simulation requires a lot of iteration and computational effort, especially for problems involving rare events (very rare events). Because of these flaws, the new Monte Carlo simulation should be used when analytical methods are not available or the approach method (e.g., first order approximation of nonlinear random variable function) is not sufficient. Monte Carlo simulation of a stochastic process is a procedure to obtain a random sample of the results of the process.

If a system contains elements that include possible factors, the model used is a stochastic model. The basis of the Monte Carlo simulation is the experiments of possibility element of using a random sample (random). In this research, Monte Carlo method is used to select the government policy in tackling unemployment through the presence of industries in Gresik. The results of the Monte Carlo method in this research can be seen in Table I.

Based on the results of Monte Carlo simulation method above, the study found the following results: first, a strong commitment between Gresik regency with the industry in order to address the problem of unemployment (a) is very necessary 
because it has the greatest impact that is $16.31 \%$. The government and the industry executors should have mutual mindset and course of action in order to solve the problem of unemployment. In terms of partnership (government and industry), both parties must encourage one another in order to improve the welfare of various targets. They must also support every policy and innovation promised and promoted by all parties to support the improvement of people's welfare.

Table I. Results of Analysis using Monte Carlo Method

\begin{tabular}{|c|c|c|c|c|c|c|c|c|}
\hline \multirow{2}{*}{$\begin{array}{l}\text { Unemployment } \\
\text { before } \\
\text { intervention }\end{array}$} & \multicolumn{7}{|c|}{ Impact of Intervention } & \multirow{2}{*}{$\begin{array}{l}\text { Unemployment } \\
\text { after } \\
\text { intervention }\end{array}$} \\
\hline & $\mathrm{a}$ & $b$ & c & $d$ & e & $f$ & Total & \\
\hline 37,347 & $\mid 6.31$ & 6.35 & 1.59 & 16.27 & 3.17 & 12.70 & 56.38 & 16,289 \\
\hline
\end{tabular}

Note:

policy interventions to address the unemployment problem:

$\mathrm{a}=$ commitment to reduce unemployment from Gresik regency and industrial /enterprise

$\mathrm{b}=$ the need to link and match between the world of education and the business world

$c=$ intense job fair

$d=$ CSR should be geared more towards empowering the unemployed

$\mathrm{e}=$ unskilled labor requirement of $100 \%$ is given to native Gresik community

$f=$ large and medium industrial partnerships with small businesses and micro

Second, CSR programs should be directed more to the activities related to the empowerment of unemployment (d) because it will have an impact in lowering the unemployment rate that is $16.27 \%$. CSR programs that will potentially become appropriate instrument to empower the local economic is certainly those that run ideal concepts and implementation techniques that are oriented to strengthening community economic competitiveness. The program should encourage initiatives to strengthen the local economy by improving the environment of competition, focus and synergy in environmental improvement efforts that optimize business industry group in one value-added link that are connected through business or non-business relationship. Moreover, the implementation of CSR programs as an instrument of economic empowerment of local communities can be done in several form, including: capital support, infrastructure development aid, assistance, institutional strengthening, and business partnership intensification.

Third, other intervention that is also important is the partnership between industry ( $f$ ) which affecting the unemployment declining up to $12.70 \%$. Strengthening 
The Impact of Industrialization on The Regional...

Sutikno, Muhammad Sri Wahyudi Suliswanto

people economic or community development in the economy does not mean merging large employers or strong economic groups, because empowerment does not mean to negate other, but give power to everybody. Community empowerment in the economic field is the joint strengthening, where the large ones will only grow if there are small and medium enterprises and the small will develop if there is a large and medium. High competitiveness only happen if there is a connection between the large with the small and medium business because, a fair production linkages will create efficiencies. Therefore, through partnerships in terms of capital, partnership in the production process, partnership in the distribution, each party will be empowered.

In the meantime, other intervention models offer relatively smaller impact. The total impact when those six kinds of recommended intervention policy (a, b, c, d, e, and $f$ ) are implemented will reduce the unemployment rate up to $56.38 \%$ in 2015 . Thus, the number of unemployed in 2015 , if the above recommendations implemented, will be reduced to 16.289 inhabitants, from 37.347 inhabitants in 2012 .

- The number of unemployed in 2012 (riel BPS data): 37.347 inhabitants

- The number of unemployed in 2013 (riel BPS data): 27.099 inhabitants

- Predictions in 2015 with ANN method without policy intervention: 26.056 inhabitants

- The number of unemployed in 2015 as the results of Monte Carlo simulation method with policy interventions: 16.289 inhabitants

\section{CONCLUSION}

Based on the results of the analysis presented in the discussion, the suggestions recommended for people around the industry are: First, the Society should be more selective with the establishment of a new industry. They should pay more attention to the villages' condition that is too densely populated and less agricultural land. Second, workers, especially factory workers must be more critical of the policies of the company, particularly related to the implemented contract system. Third, major industries are oriented to obtain maximum profit resulting from large capital and huge risk. Therefore, people must continue to improve education and skills in order to overcome the possible displacement of local communities as a result of industrial development and also to make the public no longer dependent on the existence of such companies. 
Several recommendations for companies or industries, i.e.: Firstly, Trying to find workers from the local population, in order to suppress the rate of population increase due to migration and reduce the intensity of land use. Secondly, avoid to performing development in densely populated residential area. Thirdly, industry participants must be committed to protecting the environment.

Furthermore, some recommendations for Governments are: First, the planning the industrial area should be integrated so that changes in land use patterns can be controlled and help accelerate equal distribution of development. Second, the government needs to increase the accessibility to open new industrial areas, especially in less developed regions, especially public transportation modes that will encourage investors to open up new industrial areas.

\section{REFERENCES}

Alwasilah, A.C. (2003). Pokoknya Kualitatif (The Principle of Qualitative). Jakarta: PT Dunia Pustaka Jaya \& Pusat Studi Sunda.

Armi, A., S. Soeaidy, \& A. Hayat (2016). Dampak Sosial Ekonomi Kebijakan Relokasi Pasar: Studi Kasus Relokasi Pasar Dinoyo Malang (Social and Economy Impact on Market Relocation Policy: Case Study on Relocation of Dinoyo Traditional Market at Malang City). Jurnal Administrasi Publik. 4 (I0): I- 6.

Awandari, L.P.P., \& I. Indrajaya. (2016). Pengaruh Infrastruktur, Investasi, dan Pertumbuhan Ekonomi Terhadap Kesejahteraan Masyarakat Melalui Kesempatan Kerja (The Effect of Infrastructure, Investment, and Economic Growth to Community Welfare Through Employment Opportunity). E-Jurnal Ekonomi Pembangunan Universitas Udayana. 5(I2): |435-I462.

Erista, A.A. (20I4). Dampak Industri Terhadap Perubahan Sosial Dan Ekonomi Masyarakat Di Desa Tobat Kecamatan Balaraja Tangerang Banten (The Impact of Industry to The Changes of Social and Economic in Tobat Village, Balaraja, Tangerang, Banten). (Unpublished Bachelor Thesis). Jakarta: Universitas Islam Negeri Syarif Hidayatullah Jakarta.

Istiqomah, N., \& D. Prasetyani. (20I3). Analisis Dampak Keberadaan Kawasan Industri di Desa Butuh Terhadap Peningkatan Aktivitas Perekonomian Masyarakat di Kecamatan Mojosongo Kabupaten Boyolali (The Impact Analysis of Industrial Area Existence in Butuh Village to The Community Economic Activity 
The Impact of Industrialization on The Regional...

Sutikno, Muhammad Sri Wahyudi Suliswanto

Improvement in Mojosongo, Boyolali). Sustainable Competitive Advantage (SCA). 3(I): I-I I.

Kanto, S. (2003). Sampling, Validitas dan Reliabilitas dalam Penelitian Kualitatif (Sampling, Validity, and Reliability in Qualitative Research). In Bungin, B (ed). Analisis Data Penelitian Kualitatif, Pemahaman Filosofis dan Metodologis ke Arah Penguasaan Model Aplikasi (Qualitative Research Data Analysis, Philosophical and Methodological Understanding to Mastery of Application Model) . Jakarta: PT RajaGrafindo Persada. Rahmadhani, E.R., \& S. Herianingrum. (2017). Dampak Eksternalitas Positif PT. Petrokimia Gresik Terhadap Masyarakat Dalam Perspektif Maqashid (The Impact of Positive Externality in PT Petrokimia Gresik to Community in Maqashid Perspective). Jurnal Ekonomi Syariah Teori dan Terapan. 3(10): 782-799.

Sulistiawati, R. (2012). Pengaruh Investasi terhadap Pertumbuhan Ekonomi dan Penyerapan Tenaga Kerja Serta Kesejahteraan Masyarakat di Provinsi di Indonesia (The Impact of Investment to Economic Growth, Employment, and Community Welfare in Indonesia). Jurnal Ekonomi, Bisnis dan Kewirausahaan (JEBIK). 3(I): 29-50.

Sumanto, A. (2016). Pengaruh Kredit Investasi dan Kredit Modal Kerja Terhadap Kesejahteraan Masyarakat Kabupaten/Kota di Jawa Timur (The Impact of Investment Credit and Capital Credit to Community Welfare in East Java). Jurnal Ekonomi dan Studi Pembangunan (JESP). 8 (I): 40-49.

Syahputra, Y. (2016). Dampak Sosial Ekonomi Masyarakat atas Keberadaan PT. Rapp

Estate Baserah di Kecamatan Kuantan Hilir Kabupaten Kuantan Singingi (The Socio Economic Impact of Community from The Existence of PT Rapp Estate Baserah In Kuantan Hilir, Kuantan Singingi). (Unpublished Dissertation). Riau: Universitas Islam Negeri Sultan Syarif Kasim Riau.

Tambunan, T. (1999). Perkembangan Industri Skala Kecil di Indonesia (The Development of Small Enterprise in Indonesia). Jakarta: Mutiara Sumber Widya. 